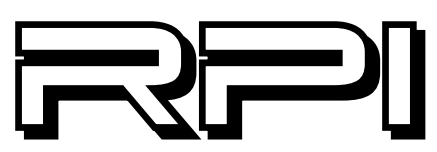

REFLEKSI PEMBELAJARAN INOVATIF

P-ISSN. 2654-6086

E-ISSN. 2656-3991

Direkrotrat Pengembangan Akademik (DPA), Universitas Islam Indonesia (UII)

Riwayat Artikel:

Dikirim: 8 Juli 2020

Direvisi: 13 Agustus 2020

Diterima: 10 September 2020

Jenis Artikel:

Penelitian Empiris

\section{Maulidyati Aisyah}

Sigit Pamungkas

Fakultas Bisnis dan Ekonomika

Universitas Islam Indonesia

Jln. Kaliurang Km. 14,5

Yogyakarta

\section{Corresponding Author: \\ Maulidyati Aisyah \\ घmaulidyati@uii.ac.id}

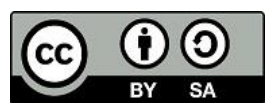

This is an open access under CC-BY-SA license

\section{Permainan Peran dan Penggunaan Teknologi Pada Proses Pembelajaran Mahasiswa Program Studi Akuntansi}

\section{Abstrak}

Pengembangan metode pengajaran dalam mata kuliah bermuatan sistem dan teknologi informasi yang didominasi dengan konsep dan praktik pada ranah teknis menjadi tantangan tersendiri bagi pendidikan sarjana program studi akuntansi. Penelitian ini menganalisis studi percontohan yang menggunakan permainan peran dan aplikasi teknologi pada mata kuliah Analisis dan Desain Sistem (ADS) yang diikuti oleh mahasiswa S1. Analisis persepsi mahasiswa terhadap peningkatan pemahaman dan alat asesmen untuk mengukur pemenuhan CPMK menunjukkan hasil yang signifikan. Metode ini dapat dijadikan alternatif untuk mendukung peningkatan kualitas pembelajaran yang berpusat pada mahasiswa, terutama untuk mata kuliah yang memiliki karakteristik serupa.

Kata kunci: Permainan peran, pendidikan akuntansi, experiential learning, teknologi informasi

\section{Abstract}

The development of teaching methods in studying subjects with information systems and technology content which are dominated by concepts and practices in the technical realm remain a challenge in the undergraduate accounting program. This research analyzes a pilot study using role playing and technology applications applied to the System Analysis and Design (ADS) course attended by undergraduate students. Analysis of students' perceptions of increased understanding and assessment tools to measure the fulfillment of learning outcomes showed significant results. This method can be used as an alternative to support the improvement student-centered learning, especially for subjects that have common characteristics.

Keywords: Role play, accounting education, experiential learning, information technology

Sitasi: Aisyah, M., Pamungkas, S. (2020). Permainan Peran dan Penggunaan Teknologi Pada Proses Pembelajaran Mahasiswa Program Studi Akuntansi. Refleksi Pembelajaran Inovatif, 2(2), 317-326.

https://doi.org/10.20885/rpi.vol2.iss2.art3 


\section{Pendahuluan}

Kemajuan pesat teknologi informasi dan pemanfaatannya pada berbagai skala implementasi dan aspek kehidupan manusia telah menghadirkan perubahan dan perkembangan lingkungan dengan laju yang semakin cepat. Gelombang disrupsi yang dibawa bersama kemajuan teknologi informasi, dengan Internet sebagai penggeraknya, memunculkan banyak peluang tantangan baru bagi dunia pendidikan tinggi untuk mampu melakukan inovasi pembelajaran dengan cepat dan responsif terhadap berbagai perubahan (Ahmad, 2015). Bagi institusi perguruan tinggi (PT), basis metode pengajaran dan ilmu pengetahuan yang ada kini semakin cepat usang sehingga PT dituntut untuk semakin adaptif dalam menciptakan kemajuan atau kebaruan di dalam pengembangan suatu ilmu pengetahuan.

Rancangan kurikulum pendidikan sarjana pada program studi akuntansi tidak hanya memuat pembelajaran ilmu akuntansi keuangan yang prinsipiel, namun juga mencakup bidang ilmu bisnis yang lebih luas, termasuk di dalamnya adalah muatan pembelajaran tentang Sistem dan Teknologi Informasi (STI). Lembaga internasional seperti American Accounting Association (AAA) dan Advance Collegiate Schools of Business International (AACSB) telah menekankan pentingnya mengintegrasikan pengetahuan tentang teknologi dan sistem informasi serta keterampilan analisis data ke dalam kurikulum akuntansi (Andiola et al., 2020; Sledgianowski et al., 2017). Pada tren yang berkembang saat ini, banyak industri yang lebih tertarik pada lulusan dengan pendidikan berbasis luas karena mereka akan memiliki pengetahuan dan keterampilan di berbagai bidang yang dapat diterapkan di tempat kerja sehingga PT perlu mempertimbangkan untuk beralih dari struktur kurikulum yang kaku ke kurikulum yang fleksibel dan berbasis luas untuk menghasilkan lulusan yang berkualitas dan tangguh (Seah et al., 2020).

Salah satu contoh mata kuliah bermuatan sistem dan teknologi informasi yang diajarkan pada kurikulum pendidikan sarjana ilmu bisnis, termasuk pada program studi akuntansi, adalah Analisis dan Desain Sistem (ADS). Sebagai calon profesional maupun manajer perusahaan modern yang akan terlibat aktif dalam perancangan dan pengembangan STI, mahasiswa program studi akuntansi di jenjang sarjana perlu dibekali dengan kemampuan untuk memahami, menjelaskan, menganalisis, serta mengimplementasikan konsep dan teknik desain sistem. Namun demikian, muatan pembelajaran STI yang didominasi dengan terminologi yang berkaitan dengan ilmu informatika tentu menjadi tantangan tersendiri bagi mahasiswa program studi akuntansi untuk dapat mempelajarinya dalam waktu yang relatif singkat. Porsi muatan pembelajaran STI di dalam kurikulum akuntansi terbatas sesuai dengan natur bidang ilmu yang dimilikinya. Proses pembelajaran suatu bidang ilmu pada kelompok mahasiswa dengan latar belakang keilmuan dan identitas sosial yang berbeda akan memunculkan perbedaan kontekstual sehingga diperlukan pendekatan didaktik yang sesuai dengan kebutuhan masing-masing kelompok (Maresch et al., 2016).

Di sisi lain, pengembangan metode pengajaran berbasis teknologi tidak hanya sebatas pada penggunaan perangkat komputer dan aplikasi perangkat lunak. Upaya pengembangan teknologi pedagogi dengan memanfaatkan kemampuan teknologi Internet seperti digitalisasi konten, automasi penyampaian, atau kolaborasi daring, tidak serta merta menghasilkan hasil pendidikan yang unggul secara materi (Fogarty, 2018). Perguruan tinggi, termasuk para dosen di dalamnya, perlu mengembangkan metode pengajaran yang atraktif dan interaktif untuk mendorong pemenuhan capaian pembelajaran mata kuliah (CPMK) dan peningkatan kualitas pembelajaran yang berpusat pada mahasiswa (student centered learning). Proses pembelajaran perlu memberikan pemahaman konseptual dan pengalaman praktis yang relevan. Pembelajaran yang holistik dan berbasis pengalaman (experiential learning) dapat mendorong kepuasan mahasiswa dan kepercayaan diri karier mereka di masa depan (Caza et al., 2015). 
Penelitian ini ditujukan untuk mengkaji penggunaan permainan peran (role playing) dan penggunaan teknologi dalam pemenuhan CPMK. Dalam riset ini, studi percontohan menggunakan pendekatan experiential learning (EL) dilakukan melalui penggunaan teknologi perangkat lunak pada komponen asesmen individu serta simulasi peran untuk merancang prototipe aplikasi non operasional yang diterapkan pada asesmen kelompok di mata kuliah Analisis dan Desain Sistem. Secara spesifik, rumusan masalah yang akan dijawab dalam penelitian ini adalah:

1. Apakah penerapan metode pengajaran dengan pendekatan permainan peran (role playing) dan penggunaan teknologi dapat mendukung peningkatan pemahaman mahasiswa terhadap topik atau materi perkuliahan dan pencapaian CPMK pada mata kuliah ADS?

2. Apakah alat asesmen yang digunakan pada metode pengajaran ini dapat mendukung pencapaian CPMK pada mata kuliah ADS?

\section{Kajian Pustaka}

Kekuatan teknologi digital dan globalisasi yang menyertainya telah mengubah banyak peran profesi secara signifikan, termasuk diantaranya adalah profesi akuntansi (Pincus et al., 2017). Desain pendidikan sarjana untuk program studi akuntansi tidak bisa menampik kebutuhan untuk menyertakan penguasaan STI sebagai bagian dari rancangan kurikulum dan kompetensi lulusan. International Accounting Education Standards Board (2019) menerbitkan standar internasional sebagai panduan untuk perancangan kurikulum akuntansi dimana kompetensi teknis akuntan profesional yang diuraikan di dalam International Education Standards (IES) 2 mencakup kompetensi teknologi informasi dan komunikasi.

Mahasiswa yang mengikuti perkuliahan pada tahun akademik 2019/2020 mencakup generasi post-millennial atau kerap disebut sebagai Generasi Z. Untuk memahami karakteristik khas generasi ini, Scholz dan Vyugina (2019) mendeskripsikan Generasi Z sebagai anggota masyarakat era informasi yang terlahir dengan natur digital (sebagai pribumi digital murni) dan terbentuk menjadi audiens media yang paling aktif dengan tingkat literasi teknologi dan kemampuan akses cepat yang membuat mereka lebih kuat dibandingkan generasi pendahulunya. Merujuk pada deskripsi karakteristik ini, maka diperlukan inovasi metode pengajaran untuk menghadirkan model pembelajaran yang sesuai bagi Generasi Z dengan memadukan pemanfaatan teknologi informasi dan fokus pendekatan belajar yang berpusat pada mahasiswa.

Dalam topik riset yang terkait dengan kewirausahaan, Generasi Z menilai bahwa pendidikan telah memberikan dampak yang signifikan terhadap peningkatan orientasi individu dan intensi terhadap kewirausahaan (Frunzaru \& Cismaru, 2018). Hal ini menunjukkan bahwa mahasiswa saat ini tetap memandang pendidikan sebagai sarana penting untuk memantik dan meningkatkan pemahaman terhadap suatu topik pembelajaran. Menyoroti pentingnya adaptasi terhadap karakteristik khas Generasi Z serta urgensi kebaruan pada strategi pengajaran, maka perlu disadari bahwa ada kebutuhan untuk mengubah model pedagogi tradisional dan dengan teknik pengajaran modern berbasis teknologi yang holistik dan praktikal.

Pendidikan dengan pendekatan EL dapat dilakukan dengan dukungan teknologi seperti simulasi komputer untuk meningkatkan kedekatan proses belajar dengan pengalaman dunia nyata (Bandera et al., 2018) dan memfasilitasi peningkatan kemampuan berpikir kritis mahasiswa (Butler et al., 2019). Meski tidak banyak riset lampau yang ditemukan, namun permainan peran merupakan salah satu teknik yang digunakan dalam aktivitas EL pada pendidikan akuntansi (Gittings et al., 2020). Permainan peran adalah metode belajar aktif melalui kegiatan kelompok yang melibatkan lebih dari satu orang yang mengambil peran berbeda dalam situasi tertentu dengan tujuan untuk memperoleh pengalaman belajar (Acharya et al., 2019). Beberapa penelitian 
Permainan Peran dan Penggunaan Teknologi Pada Proses Pembelajaran Mahasiswa Program Studi Akuntansi

telah mengkaji penggunaan permainan peran dalam pengajaran di bidang ilmu keperawatan (Delnavaz et al., 2018; Mishima et al., 2012) dan ilmu politik (Duchatelet et al., 2019).

\section{Metode Penelitian}

Penelitian ini menggunakan studi percontohan yang diterapkan pada mata kuliah Analisis dan Desain Sistem. Mata kuliah ADS merupakan salah satu mata kuliah wajib di dalam gugus mata kuliah sistem informasi yang ada pada kurikulum pendidikan sarjana Program Studi Akuntansi di Fakultas Bisnis dan Ekonomika, Universitas Islam Indonesia. Satu kelas ADS dengan jumlah mahasiswa sebanyak 44 orang dijadikan subjek percontohan pada penelitian ini.

Mata kuliah ADS memiliki cakupan materi perkuliahan yang cukup kompleks bagi mahasiswa akuntansi karena mempelajari berbagai konsep teknis yang memadukan pemahaman konseptual terkait pembelajaran dalam ilmu komputer (informatika) dengan perspektif manajerial dalam menjalankan peran sebagai pengelola organisasi bisnis modern. Kompleksitas analisis dan desain sistem informasi acapkali memerlukan pendekatan yang terstruktur sekaligus intuitif, serta melibatkan kerja yang berlapis-lapis (multi-layered), baik menyangkut proses maupun pemangku kepentingan yang terlibat di dalam proyek pengembangan sistem informasi (Kendall \& Kendall, 2019). Oleh sebab itu, untuk mendukung pembelajaran yang optimal pada mata kuliah ADS, mahasiswa perlu memiliki pengalaman melalui simulasi peran sebagai manajer untuk dapat memahami kompleksitas sistem informasi bagi organisasi bisnis, serta simulasi peran sebagai analis atau perancang sistem informasi untuk dapat memahami kompleksitas pengelolaan project management dalam mendesain dan mengembangkan aplikasi sistem informasi tersebut.

Studi percontohan diawali dengan pemetaan CPMK beserta indikatornya (lihat Tabel 1) untuk menentukan alat asesmen. Dalam studi percontohan ini, beberapa alat asesmen, baik individu maupun kelompok, dirancang dengan menggunakan perangkat teknologi melalui beberapa aplikasi berbasis web seperti Kahoot, MindMup, dan Figma.

Tabel 1. CPMK, Indikator, dan Alat Asesmen

\begin{tabular}{lcl}
\hline \multicolumn{1}{c}{ CPMK } & Indikator & \multicolumn{1}{c}{ Asesmen } \\
\hline $\begin{array}{l}\text { 1. Mampu memahami dan } \\
\text { menjelaskan konsep dan } \\
\text { teknik desain sistem }\end{array}$ & $\begin{array}{c}\text { 1.1. Mampu memahami konsep } \\
\text { dasar analisis sistem }\end{array}$ & $\begin{array}{l}\text { Asesmen individu: } \\
\text { - Kuis (Kahoot); }\end{array}$ \\
& $\begin{array}{c}\text { 1.2. Mampu memahami konsep } \\
\text { analisis kebutuhan informasi }\end{array}$ & $\begin{array}{l}\text { - Peta konsep } \\
\text { (MindMup); }\end{array}$ \\
& $\begin{array}{c}\text { 1.3. Mampu memahami proses } \\
\text { analisis dan desain sistem }\end{array}$ & - Ujian (UTS dan \\
& $\begin{array}{l}\text { 1.4. Mampu memahami konsep } \\
\text { quality assurance sebuah } \\
\text { sistem }\end{array}$ & \\
& $\begin{array}{c}\text { 2.1. Mampu mendesain aliran data } \\
\text { pada suatu proses bisnis }\end{array}$ & $\begin{array}{l}\text { Asesmen kelompok: } \\
\text { - Permainan peran } \\
\text { (role playing) }\end{array}$ \\
\hline $\begin{array}{l}\text { 2. Mampu menganalisis dan } \\
\text { mengimplementasikan } \\
\text { konsep dan teknik desain } \\
\text { sistem }\end{array}$ & $\begin{array}{c}\text { 2.2. Mampu mendesain prototipe } \\
\text { aplikasi non operasional }\end{array}$ & $\begin{array}{l}\text { Desain prototipe } \\
\text { aplikasi non }\end{array}$ \\
& & operasional (Figma) \\
\hline
\end{tabular}

Secara khusus, konsep permainan peran di dalam tugas kelompok dirancang melalui simulasi peran sebagai manajer organisasi bisnis (Peran 1) dan sebagai analis sistem (Peran 2) untuk melakukan sebuah project management sederhana pembuatan prototipe aplikasi non- 
operasional. Skenario Peran 1 memberikan tugas kepada setiap kelompok untuk merancang persyaratan proses bisnis untuk kebutuhan pengembangan aplikasi yang disajikan pada laporan yang memuat desain aliran data. Sedangkan Peran 2 memberikan tugas kepada setiap kelompok untuk membuat desain prototipe aplikasi non operasional berdasarkan kebutuhan manajer yang telah dibuat pada Peran 1. Mahasiswa di dalam kelas dibagi menjadi kelompok dengan jumlah genap sehingga dapat dibuat pasangan kelompok. Skenario tugas didesain agar setiap kelompok memiliki pengalaman Peran 1 dan Peran 2 dengan saling bertukar peran dengan kelompok mitra (lihat Gambar 1).

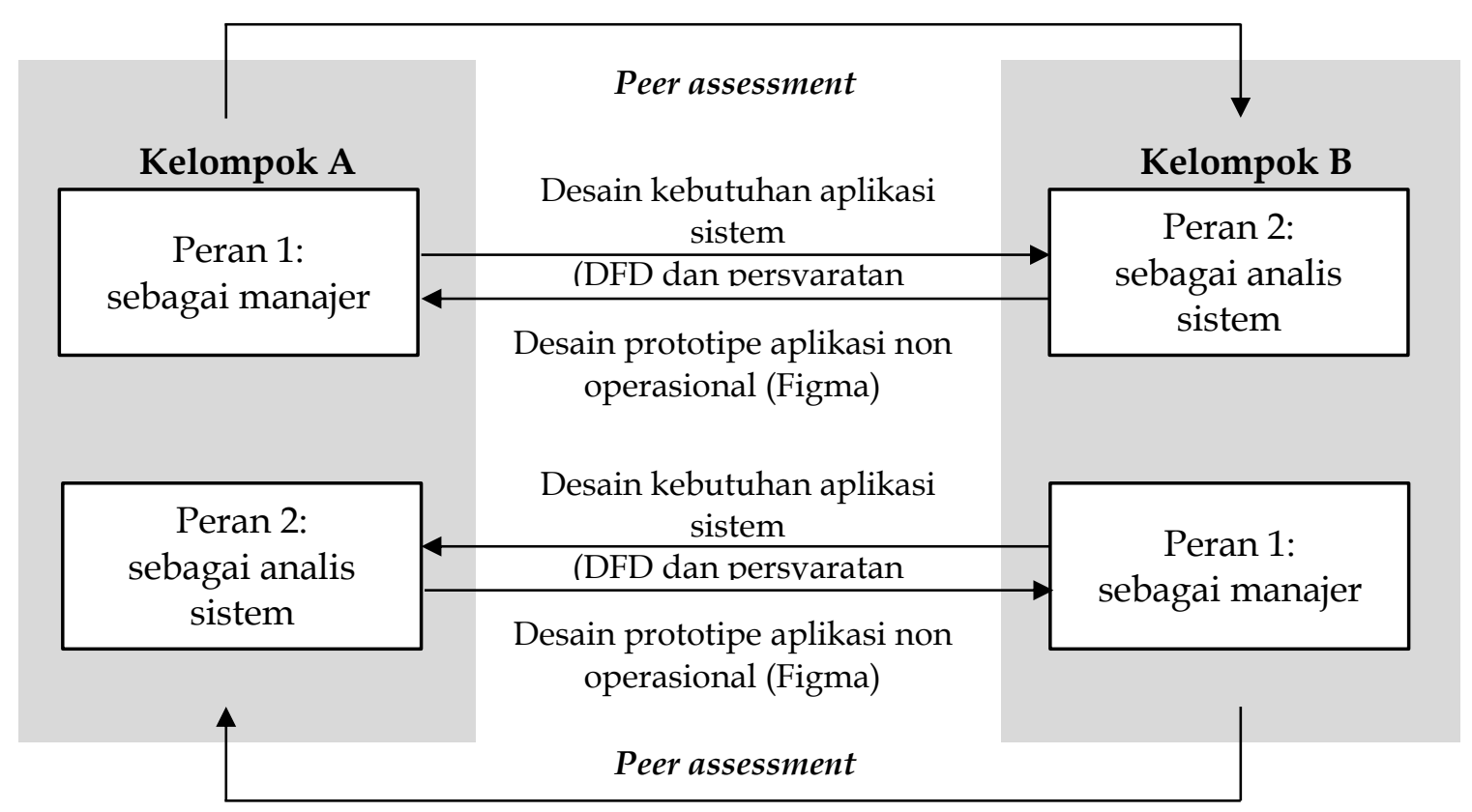

Gambar 1. Alur Pelaksanaan Permainan Peran

Hasil studi percontohan ini akan dianalisis menggunakan teknik skala non komparatif berdasarkan data yang diperoleh dari kuesioner daring untuk mengukur persepsi mahasiswa terhadap metode pengajaran yang digunakan dan pemenuhan CPMK sesuai tujuan penelitian ini (lihat Tabel 2).

Tabel 2. Metode Pengukuran dan Target

\begin{tabular}{|c|c|c|}
\hline Rumusan Masalah & Metode Pengukuran & Target \\
\hline $\begin{array}{l}\text { Peningkatan pemahaman mahasiswa } \\
\text { terhadap topik/materi perkuliahan dan } \\
\text { pencapaian CPMK }\end{array}$ & $\begin{array}{l}\text { Pengukuran tingkat } \\
\text { kepuasan mahasiswa } \\
\text { (Likert scale } 1-5 ; \text { non- } \\
\text { comparative scaling) }\end{array}$ & $\begin{array}{l}75 \% \text { mahasiswa } \\
\text { menyatakan puas }\end{array}$ \\
\hline $\begin{array}{l}\text { Penggunaan alat asesmen terhadap } \\
\text { pencapaian CPMK }\end{array}$ & $\begin{array}{l}\text { Pengukuran tingkat } \\
\text { kepuasan mahasiswa } \\
\text { (Likert scale } 1-5 ; \text { non- } \\
\text { comparative scaling) }\end{array}$ & $\begin{array}{l}75 \% \text { mahasiswa } \\
\text { menyatakan puas }\end{array}$ \\
\hline
\end{tabular}


Permainan Peran dan Penggunaan Teknologi Pada Proses Pembelajaran Mahasiswa Program Studi

\section{Hasil Penelitian dan Pembahasan}

Analisis persepsi mahasiswa dengan menggunakan metode skala non komparatif telah dilakukan pada penelitian lampau, misal pada studi percontohan tentang pembelajaran digital bagi mahasiswa ilmu bisnis dan teknik (Fleaca \& Stanciu, 2019). Dalam penelitian ini, batasan studi ditetapkan hanya pada persepsi mahasiswa untuk mengukur pencapaian CPMK melalui metode pengajaran yang diterapkan. Untuk mencapai tujuan penelitian, mahasiswa diminta untuk menandai tingkat kepuasan atau persetujuan mereka sehubungan dengan beberapa pernyataan yang digunakan untuk mengukur peningkatan pemahaman dan penggunaan alat asesmen terkait terhadap pemenuhan CPMK. Skala Likert 5 poin digunakan dengan rentang penilaian 1 - sangat tidak setuju/sangat tidak puas, hingga 5 - sangat setuju/sangat puas. Hasil analisis data disajikan pada Tabel 3 dan Tabel 4.

Tabel 3. Hasil Analisis Peningkatan Pemahaman Terhadap Topik/Materi Kuliah dan Pencapaian CPMK

\begin{tabular}{lllllllll}
\hline $\begin{array}{l}\text { Peningkatan pemahaman } \\
\text { terhadap topik/materi } \\
\text { perkuliahan dan } \\
\text { pencapaian CPMK }\end{array}$ & $\mathbf{1}$ & $\mathbf{2}$ & $\mathbf{3}$ & $\mathbf{4}$ & $\mathbf{5}$ & $\begin{array}{l}\text { Weighted } \\
\text { Score }\end{array}$ & $\begin{array}{l}\text { Tingkat } \\
\text { kepuasan }\end{array}$ & Hasil \\
\hline $\begin{array}{c}1.1 \text { Konsep dasar analisis } \\
\text { sistem }\end{array}$ & 0 & 0 & 4 & 30 & 10 & $\mathbf{4 , 1 4}$ & $\mathbf{9 1 \%}$ & Tercapai \\
\hline $\begin{array}{c}1.2 \text { Analisis kebutuhan } \\
\text { informasi }\end{array}$ & 0 & 0 & 8 & 31 & 5 & $\mathbf{3 , 9 3}$ & $\mathbf{8 2 \%}$ & Tercapai \\
\hline $\begin{array}{c}1.3 \text { Proses analisis dan } \\
\text { desain sistem }\end{array}$ & 0 & 2 & 6 & 27 & 9 & $\mathbf{3 , 9 8}$ & $\mathbf{8 2 \%}$ & Tercapai \\
\hline $\begin{array}{c}1.4 \text { Konsep quality } \\
\text { assurance }\end{array}$ & 0 & 3 & 9 & 24 & 8 & $\mathbf{3 , 8 4}$ & $\mathbf{7 3 \%}$ & Tidak \\
\hline $\begin{array}{c}\text { 2.1 Desain aliran data } \\
\text { proses bisnis }\end{array}$ & 0 & 1 & 6 & 18 & 19 & $\mathbf{4 , 2 5}$ & $\mathbf{8 4 \%}$ & Tercapai \\
\hline $\begin{array}{c}\text { 2.2 Desain prototipe } \\
\text { aplikasi non operasional }\end{array}$ & 0 & 0 & 5 & 25 & 14 & $\mathbf{4 , 2 0}$ & $\mathbf{8 9 \%}$ & Tercapai \\
\hline
\end{tabular}

Tabel 4. Hasil Analisis Alat Asesmen Terhadap Pencapaian CPMK

\begin{tabular}{lllllllll}
\hline $\begin{array}{l}\text { Pengaruh alat asesmen } \\
\text { terhadap pencapaian } \\
\text { CPMK }\end{array}$ & $\mathbf{1}$ & $\mathbf{2}$ & $\mathbf{3}$ & $\mathbf{4}$ & $\mathbf{5}$ & $\begin{array}{l}\text { Weighted } \\
\text { Score }\end{array}$ & $\begin{array}{l}\text { Tingkat } \\
\text { kepuasan }\end{array}$ & Hasil \\
\hline Kuis (Kahoot) & 0 & 2 & 7 & 25 & 10 & $\mathbf{3 , 9 8}$ & $\mathbf{8 0 \%}$ & Tercapai \\
\hline Peta konsep (MindMup) & 0 & 2 & 4 & 24 & 14 & $\mathbf{4 , 1 4}$ & $\mathbf{8 6 \%}$ & Tercapai \\
\hline Role Play 1 (DFD \& ERD) & 1 & 1 & 6 & 18 & 18 & $\mathbf{4 , 1 6}$ & $\mathbf{8 2 \%}$ & Tercapai \\
\hline Role Play 2 (Figma) & 0 & 0 & 4 & 22 & 18 & $\mathbf{4 , 3 2}$ & $\mathbf{9 1 \%}$ & Tercapai \\
\hline Peer Assessment & 0 & 1 & 13 & 19 & 11 & $\mathbf{3 , 9 1}$ & $\mathbf{6 8 \%}$ & Tidak \\
\hline Presentasi & 0 & 0 & 7 & 20 & 17 & $\mathbf{4 , 2 3}$ & $\mathbf{8 4 \%}$ & Tercapai \\
\hline Ujian (UTS \& UAS) & 2 & 0 & 8 & 18 & 16 & $\mathbf{4 , 0 5}$ & $\mathbf{7 7 \%}$ & Tercapai \\
\hline
\end{tabular}

Hasil analisis pada Tabel 3 menunjukkan tingkat kepuasan yang signifikan dan memenuhi target di atas 75, khususnya pada indikator CPMK 1.1 (91\%); 1.2 (82\%); 1.3 (82\%); 2.1 (84\%); dan 2.2 (89\%). Indikator 1.4 tidak mencapai target dengan hasil tingkat kepuasan $73 \%$, sedikit 
lebih rendah dari target yang ditetapkan namun memiliki skor rerata (weighted score) yang mencapai target $(3,91)$. Skor rerata untuk indikator CPMK lainnya menunjukkan tingkat kepuasan yang cukup signifikan dengan nilai di atas 3,00. Berdasarkan analisis data tersebut, metode pengajaran EL dengan menggunakan pendekatan permainan peran dan aplikasi teknologi menunjukkan dampak yang signifikan terhadap peningkatan pemahaman dan capaian CPMK. Hasil ini mengkonfirmasi temuan beberapa penelitian sebelumnya yang telah menerapkan permainan peran pada proses pembelajaran mahasiswa ilmu keperawatan (Delnavaz et al., 2018; Vizeshfar et al., 2019); ilmu politik (Duchatelet et al., 2019); dan mahasiswa program MBA (Acharya et al., 2019).

Sementara itu analisis data pada Tabel 4 terkait persepsi mahasiswa terhadap alat asesmen perkuliahan menunjukkan skor rerata yang melebihi target dengan pelaksanaan kuis daring menggunakan aplikasi Kahoot (3,98); peta konsep memakai aplikasi MindMup $(4,14)$; perancangan proses bisnis dengan DFD dan ERD $(4,16)$; perancangan prototipe dengan aplikasi Figma (4,32); penilaian antar mahasiswa $(3,91)$; presentasi kelompok $(4,23)$; dan pelaksanaan ujian $(4,05)$. Skor rerata ini menunjukkan respon yang positif atas metode pengajaran berbasis pengalaman yang diterapkan pada mata kuliah ADS, baik dalam aspek penggunaan teknik permainan peran serta adopsi teknologi dalam pelaksanaan beberapa komponen tugas individu maupun kelompok. Pada konteks ini, pemanfaatan teknologi untuk mendukung proses pembelajaran menjadi temuan positif sejalan dengan riset lampau yang menyoroti kebutuhan peningkatan keterampilan digital bagi mahasiswa melalui metode pengajaran berbasis teknologi (Claro et al., 2018; Fleaca \& Stanciu, 2019). Penggunaan aplikasi teknologi (seperti Kahoot atau yang sejenis) dengan fitur interaktif berbasis gim (gamification) memberi pengaruh positif terhadap proses pembelajaran (Beatson et al., 2019).

Hasil ini juga memenuhi target tingkat kepuasan dengan nilai di atas $75 \%$ kecuali pada komponen penilaian sejawat (peer assessment) yang hanya mencapai 68\%. Penggunaan peer assessment secara daring menjadi strategi untuk meningkatkan keterlibatan dan tanggung jawab mahasiswa dalam melakukan refleksi dari proses pembelajaran yang telah mereka alami (Rosa et al., 2016). Penilaian sejawat merupakan penilaian kolaboratif yang melibatkan tekanan hubungan dan persepsi interpersonal antar mahasiswa yang dapat mempengaruhi proses atau resistensi dalam melakukan penilaian (Rotsaert et al., 2018). Dalam studi percontohan ini, frekuensi kegiatan dalam pelaksanaan permainan peran menghasilkan hubungan interpersonal yang erat sehingga memunculkan tekanan terhadap penilaian yang tidak adil atau bahkan penolakan untuk berpartisipasi. Aspek ini perlu mendapat perhatian lebih lanjut melalui proses kreatif pengajar untuk memusatkan penilaian sejawat pada proses refleksi belajar, sehingga dapat meminimalisir tekanan interpersonal yang dihadapi mahasiswa dalam memberikan nilai untuk teman sebayanya.

\section{Kesimpulan dan Saran}

Penelitian ini ditujukan untuk menguji permainan peran dan penggunaan teknologi di dalam model pengajaran berbasis pengalaman (experiential learning) yang diterapkan pada mata kuliah Analisis dan Desain Sistem dan diikuti oleh mahasiswa pendidikan sarjana pada program studi akuntansi. Hasil penelitian ini menunjukkan pengaruh yang signifikan baik dalam penggunaan teknik permainan peran maupun pemakaian aplikasi berbasis web sebagai alat asesmen untuk meningkatkan proses pembelajaran dan pencapaian CPMK.

Temuan penelitian ini dapat dijadikan sebagai masukan bagi pengelola program studi maupun dosen untuk mengembangkan metode pengajaran berbasis pengalaman yang dapat diterapkan pada berbagai jenjang pendidikan tinggi, khususnya dalam penggunaan teknologi dan simulasi belajar dengan permainan peran untuk mendukung implementasi student-centered learning. 
Riset ini dilaksanakan melalui studi percontohan awal sehingga hasil analisis masih terbatas pada subjek mahasiswa dan kelas yang dijadikan percontohan. Pengembangan dari penelitian ini dapat dilakukan dengan meningkatkan jumlah responden dan melibatkan kelompok kontrol sehingga uji komparasi dapat dilakukan. Analisis tingkat penerimaan teknologi dan pengaruhnya terhadap motivasi belajar pada individu juga dapat dikembangkan dengan menggunakan beberapa teori seperti Technology Acceptance Model (TAM) atau Unified Theory of Acceptance and Use of Technology (UTAUT) pada mahasiswa (Hoi, 2020; Zheng \& Li, 2020), atau model respon afektif (Verkijika, 2020), atau menganalisis penggunaannya dari perspektif dosen atau pengajar (Scherer et al., 2019).

\section{Rekognisi}

Studi percontohan dan penelitian ini terlaksana melalui program Hibah Pengajaran yang didanai oleh Direktorat Pengembangan Akademik, Universitas Islam Indonesia tahun 2020.

\section{Daftar Pustaka}

Acharya, H., Reddy, R., Hussein, A., Bagga, J., \& Pettit, T. (2019). The effectiveness of applied learning: an empirical evaluation using role playing in the classroom. Journal of Research in Innovative Teaching \& Learning, 12(3), 295-310. https://doi.org/10.1108/jrit-06-20180013

Ahmad, T. (2015). Preparing for the future of higher education. On the Horizon, 23(4), 323-330. https://doi.org/10.1108/OTH-06-2015-0029

Andiola, L. M., Masters, E., \& Norman, C. (2020). Integrating technology and data analytic skills into the accounting curriculum: Accounting department leaders' experiences and insights. $\begin{array}{lllll}\text { Journal of Accounting } & \text { Education, } & 50, & \end{array}$ https://doi.org/10.1016/j.jaccedu.2020.100655

Bandera, C., Collins, R., \& Passerini, K. (2018). Risky business: Experiential learning, information and communications technology, and risk-taking attitudes in entrepreneurship education. International Journal of Management Education, 16(2), 224-238. https://doi.org/10.1016/j.ijme.2018.02.006

Beatson, N., Gabriel, C. A., Howell, A., Scott, S., van der Meer, J., \& Wood, L. C. (2019). Just opt in: How choosing to engage with technology impacts business students' academic $\begin{array}{lllll}\text { performance. Journal of Accounting Education, } & \text { 50, } 100641 .\end{array}$ https://doi.org/10.1016/j.jaccedu.2019.100641

Butler, M. G., Church, K. S., \& Spencer, A. W. (2019). Do, reflect, think, apply: Experiential education in accounting. Journal of Accounting Education, 48, 12-21. https://doi.org/10.1016/j.jaccedu.2019.05.001

Caza, A., Brower, H. H., \& Wayne, J. H. (2015). Effects of a holistic, experiential curriculum on business students' satisfaction and career confidence. International Journal of Management Education, 13(1), 75-83. https://doi.org/10.1016/j.ijme.2015.01.006

Claro, M., Salinas, A., Cabello-Hutt, T., San Martín, E., Preiss, D. D., Valenzuela, S., \& Jara, I. (2018). Teaching in a Digital Environment (TIDE): Defining and measuring teachers' capacity to develop students' digital information and communication skills. Computers and 
Education, 121(March), 162-174. https://doi.org/10.1016/j.compedu.2018.03.001

Delnavaz, S., Hassankhani, H., Roshangar, F., Dadashzadeh, A., Sarbakhsh, P., Ghafourifard, M., \& Fathiazar, E. (2018). Comparison of scenario based triage education by lecture and role playing on knowledge and practice of nursing students. Nurse Education Today, 70(October 2017), 54-59. https://doi.org/10.1016/j.nedt.2018.08.006

Duchatelet, D., Gijbels, D., Bursens, P., Donche, V., \& Spooren, P. (2019). Looking at role-play simulations of political decision-making in higher education through a contextual lens: A state-of-the-art. Educational Research Review, 27(March), 126-139. https://doi.org/10.1016/j.edurev.2019.03.002

Fleaca, E., \& Stanciu, R. D. (2019). Digital-age Learning and Business Engineering Education-a Pilot Study on Students' E-skills. Procedia Manufacturing, 32, 1051-1057. https://doi.org/10.1016/j.promfg.2019.02.320

Fogarty, T. J. (2018). Forces of change - Another perspective: A reply to Pincus et al. (2017). Journal of Accounting Education, 43(March), 40-42. https://doi.org/10.1016/j.jaccedu.2018.03.003

Frunzaru, V., \& Cismaru, D. M. (2018). The impact of individual entrepreneurial orientation and education on generation Z's intention towards entrepreneurship. Kybernetes. https://doi.org/10.1108/K-05-2018-0272

Gittings, L., Taplin, R., \& Kerr, R. (2020). Experiential learning activities in university accounting education: A systematic literature review. Journal of Accounting Education, 52, 100680. https://doi.org/10.1016/j.jaccedu.2020.100680

Hoi, V. N. (2020). Understanding higher education learners' acceptance and use of mobile devices for language learning: A Rasch-based path modeling approach. Computers and Education, 146(November 2019), 103761. https://doi.org/10.1016/j.compedu.2019.103761

International Accounting Education Standards Board. (2019). International Education Standard 2, Initial Professional Development - Technical Competence ( Revised) (Issue October).

Kendall, K. E., \& Kendall, J. E. (2019). Systems Analysis and Design (10th ed.). Pearson Education.

Maresch, D., Harms, R., Kailer, N., \& Wimmer-Wurm, B. (2016). The impact of entrepreneurship education on the entrepreneurial intention of students in science and engineering versus business studies university programs. Technological Forecasting and Social Change, 104, 172-179. https://doi.org/10.1016/j.techfore.2015.11.006

Mishima, Y., Saito, A., Tamura, T., Okutsu, T., Nakazawa, Y., \& Hori, S. (2012). The Small Group Role-Playing Educations Improved Hand Hygiene Compliance in Intensive Care

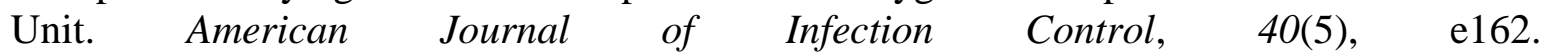
https://doi.org/10.1016/j.ajic.2012.04.286

Pincus, K. V., Stout, D. E., Sorensen, J. E., Stocks, K. D., \& Lawson, R. A. (2017). Forces for change in higher education and implications for the accounting academy. Journal of Accounting Education, 40, 1-18. https://doi.org/10.1016/j.jaccedu.2017.06.001

Rosa, S. S., Coutinho, C. P., \& Flores, M. A. (2016). Online Peer Assessment: Method and Digital Technologies. Procedia - Social and Behavioral Sciences, 228(June), 418-423. https://doi.org/10.1016/j.sbspro.2016.07.064

Rotsaert, T., Panadero, E., \& Schellens, T. (2018). Peer assessment use, its social nature challenges and perceived educational value: A teachers' survey study. Studies in Educational 
Permainan Peran dan Penggunaan Teknologi Pada Proses Pembelajaran Mahasiswa Program Studi Akuntansi

Evaluation, 59(July), 124-132. https://doi.org/10.1016/j.stueduc.2018.07.001

Scherer, R., Siddiq, F., \& Tondeur, J. (2019). The technology acceptance model (TAM): A metaanalytic structural equation modeling approach to explaining teachers' adoption of digital technology in education. Computers and Education, 128(0317), 13-35. https://doi.org/10.1016/j.compedu.2018.09.009

Scholz, T. M., \& Vyugina, D. (2019). Looking into the Future: What We Are Expecting from Generation Z. Generations Z in Europe, 277-284. https://doi.org/10.1108/978-1-78973-491120191021

Seah, K. K. C., Pan, J., \& Tan, P. L. (2020). Breadth of university curriculum and labor market outcomes. Labour Economics, 65(June). https://doi.org/10.1016/j.labeco.2020.101873

Sledgianowski, D., Gomaa, M., \& Tan, C. (2017). Toward integration of Big Data, technology and information systems competencies into the accounting curriculum. Journal of Accounting Education, 38, 81-93. https://doi.org/10.1016/j.jaccedu.2016.12.008

Verkijika, S. F. (2020). An affective response model for understanding the acceptance of mobile payment systems. Electronic Commerce Research and Applications, 39(November 2019), 100905. https://doi.org/10.1016/j.elerap.2019.100905

Vizeshfar, F., Zare, M., \& Keshtkaran, Z. (2019). Role-play versus lecture methods in community health volunteers. Nurse Education Today, 79(April), 175-179. https://doi.org/10.1016/j.nedt.2019.05.028

Zheng, J., \& Li, S. (2020). What drives students' intention to use tablet computers: An extended technology acceptance model. International Journal of Educational Research, 102(November 2019), 101612. https://doi.org/10.1016/j.ijer.2020.101612 